\title{
Konstruowanie Galla. Problem oralności jako problem interpretacyjny tekstu
}

\author{
DOI: http://dx.doi.org/10.12775/LC.2016.040
}

Streszczenie: Żywa w ostatniej dekadzie dyskusja na temat Gestów Galla traci wiele bez rozważenia literackich konwencji czy topiki. Gall jest autorem, którego dzieło wchodzi bezpośrednio w złożone związki z tekstami ustnymi. Nieprzypadkowo odnosi się on do związku literackich i oralnych tradycji, które integruje w tekście przeznaczonym do cichej lektury. Przeszkodą w rozumieniu społecznej rzeczywistości Galla jest dwuznaczność użytych konwencji, wszystkich sformułowań kronikarza nie można traktować dosłownie. Rozważania filologiczne i historiograficzne w artykule opierają się na konstruktywizmie.

Słowa kluczowe: Gall Anonim, gesta, literatura średniowieczna, figury retoryczne, oralność

Abstract: A vivid debate in the last decade over Gallus Anonymous' Gesta looses a lot without seeing of literary conventions and topoi. Gallus is the author whose work directly enters into a complex relationship with oral texts. Gall does make not occasional reference to the combination of literary and oral traditions, both of which he incorporated into the text designed for silently reading. The ambiguity in the used conventions is the basic hindrance in comprehension of Gallus' social reality, all of Authors' expressions can be read not verbatim. The philological and historical approach in this paper based on constructivism.

Keywords: Gallus Anonymous, gesta, medieval literature, rhetorical figures, orality

\footnotetext{
* Adiunkt w Instytucie Polonistyki i Kulturoznawstwa Uniwersytetu Szczecińskiego. Jego przedmiot badań stanowią społeczne i kulturowe uwarunkowania literatury dawnej, szczególnie na obszarze kultury dworskiej XVI stulecia oraz tzw. literatury mieszczańskiej. Obecne jego zainteresowania związane są m.in. z recepcją zachodnich narracji epickich w twórczości polskiej (czy związanej z kulturą Polski) po XVII stuleciu. E-mail: witold. wojtowicz@interia.pl.
} 
nonim tzw. Gall ${ }^{1}$ jest przykładem autora, którego dzieło wchodzi w złożone związki z literaturą ustną ${ }^{2}$. Autor, wnosząc żywioł oralności do dzieła łacińskiego, zapewnił sobie wymiar epicki rzeczywistości przedstawionej. Gesta od samego początku są literaturą „książkową”, włączone w klerycką kulturę pisma ${ }^{3}$. Z jednej strony mamy zatem swego rodzaju residuum oralne przejętych narracji, gros materiału Galla pochodzi, jak się powszechnie przyjmuje, z opowieści znanych mu de auditu. $\mathrm{Z}$ drugiej zaś strony Gallowe „chanson de geste” jest tekstem, „literaturą książkową”, od samego początku zakłada włączenie treści „epickich” w kościelną i łacińską kulturę pisma jako narzędzia zaawansowanej kultury

Dennis Howard Green zwraca uwagę na heterogeniczność społeczną i intelektualną dworu europejskiego, pisze o „twofold reception”, o możliwości, że teksty odbierano w wystąpieniu/recytacji, ale także - czytano indywidualnie ${ }^{5}$. Nie wiemy w zasadzie nic o okolicznościach tworzenia tekstu przez Galla. Przyjęto milcząco, że Gesta powstawały na dworze Bolesława Krzywoustego, jednakże nie jest to oczywiste. Nie wiemy, czy Gesta powstawały na dworze książęcym, czy raczej na dworze któregoś z biskupów lub w którymś z opactw ${ }^{6}$.

Gall jest jednym z tych autorów, którzy wydarzenia ze swej bliskiej przeszłości i z teraźniejszości oceniają ze względu na znaczenie dla potomnych i oddziaływanie na nich. Samo istnienie pisemnego przekazu jest bardzo ważnym wyróżnikiem kulturowej pozycji społeczności, której dzieje ujęte są pisemną narracją. Podkreśla to w „polemice” z obtrectatores

1 Odwołuję się do: Anonim tzw. Gall, Kronika polska, przeł. R. Grodecki, przekład oprac., wstęp, przypisy M. Plezia, Wrocław 1989. Skrótem GC opatruję lokalizację w edycji łacińskiej: Galli Anonymi, Cronicae et gesta ducum sive principum Polonorum, wyd., wstęp, komentarz K. Maleczyński. Kraków 1952.

2 Zob. R. Kellog, Literatura ustna, przeł. P. Czapliński, „Pamiętnik Literacki” 1990, z. 1, s. 250. W odniesieniu do badań nad Gallem - zob. E. Skibiński, Elementy historii oralnej w kronikach Galla Anonima i Wincentego Kadłubka, [w:] Kultura piśmienna średniowiecza i czasów nowożytnych. Problemy i konteksty badawcze, red. P. Dymmel, B. Trelińska, Lublin 1998, s. 63-72; W. Polak, "Gesta" Gallowe a kultura oralna, [w:] Tekst. Źródła. Krytyka. Interpretacja, red. B. Trelińska, Warszawa 2005, s. 65-75; P. Wiszewski, Domus Boleslai. W poszukiwaniu tradycji dynastycznej Piastów (do około 1138 roku), Wrocław 2008, s. 170-173. Zob. także: T. Michałowska, Między słowem mówionym a pisanym. (O poezji polskiej późnego średniowiecza), [w:] Literatura i kultura późnego średniowiecza w Polsce, red. T. Michałowska, Warszawa 1993, s. 82-114; oraz K. Targosz, Gesta principum recitata. „Teatr czynów polskich władców” Galla Anonima, "Pamiętnik Teatralny” 1980, nr 2, s. 141-178.

3 Brygida Kürbis (Pisarze i czytelnicy w Polsce XII i XIII wieku, [w:] Polska dzielnicowa i zjednoczona. Państwo, społeczeństwo, kultura, red. A. Gieysztor, Warszawa 1972, s. 177) rozważała możliwość melorecytacji kroniki „W komnacie książęcej i wśród kleryków” (co wydaje się pogłosem rozważań Galla z III Listu). Autorka nie wskazała jednak na potencjalnych wykonawców tego „performansu”. Nie mamy żadnego zewnętrznego świadectwa istnienia „publiczności” Galla. Nie należy traktować sugestii co do transmisji oralnej Gestów jako związanych z faktyczną rzeczywistością reprodukcji tekstu. Należy natomiast przyznać Gallowi bardzo rozwiniętą świadomość fikcji.

${ }^{4} \mathrm{Na}$ rolę topiki (przykładowo idealnego władcy), która modeluje narrację dotyczącą czasów Bolesława Chrobrego, jak i samą postać tegoż władcy, a także pozwala Gallowi przekształcać tradycje ustne, wskazywał W. Polak "Gesta" Gallowe, s. 66. Zwraca uwagę szczupłość tych treści udostępnianych czy dostępnych Gallowi.

5 D. H. Green, Medieval Listening and Reading. The Primary Reception of German Literature 800-1300, Cambridge-New York 1994, np. s. 10-12, 101 i n. Praca ta, podobnie jak dalej przywołane, posiłkuje się odnośnymi rozważaniami Waltera Onga (ibidem, s. 3 i n.).

6 Zob. analizy Gerarda Labudy pomieszczone w: Miejsce powstania kroniki Anonima Galla, [w:] Prace z dziejów Polski feudalnej ofiarowane Romanowi Grodeckiemu w 70 rocznicę urodzin, red. K. Stachowska, Warszawa 1960, s. 107-122. O problematyce tej w mediewistyce światowej zob. tom Mittelalterliche Literatur und Kunst im Spannungsfeld von Hof und Kloster Ergebnisse der Berliner Tagung, 9.-11. Oktober 1997, Hg. N. F. Palmer, H.-J. Schiewer, Tübingen 1999. 
(invidiosi, calumpniatores itp.), uprzedzając krytykę odbiorców (w czym dopatrywać się należy przede wszystkim siły tradycji literackiej) ${ }^{7}$ :

Bo jeżeli sądzicie, że królowie i książęta polscy nie zasługują na własne dzieje i roczniki, to najwidoczniej królestwo polskie stawiacie na równi z jakimi bądź niekulturalnymi ludami barbarzyńców ${ }^{8}$ [List III, s. 122].

Polakom nie uchodzi pozostawać w tyle za innymi gentes, należącymi do świata łacińskiego i chrześcijańskiego. Rzekomy osąd, który wygłasza obtrectator, powinien z kolei zostać zrozumiany jako retoryczna prolepsis. Cała sytuacja narracyjna, doniosła w wymiarze symbolicznym, jest raczej elementem konwencji fikcji, co wskazuje na olbrzymią jej rolę u Galla.

Najbardziej wyraźnym (prócz aspektów poetologicznych) ${ }^{9}$ dziedzictwem tradycji oralnych przejętych przez kronikarza jest „niedookreślenie” przez „dane”, oparte na tradycji piśmiennej, jakichkolwiek wywodów i rozważań Galla (szczególnie w pierwszej księdze). Mamy do czynienia z efektywnym mechanizmem utożsamiania się postaci i czynów, pozostających w zasięgu udostępnianej Gallowi tradycji ustnej ${ }^{10}$. Kulturowym tłem jest brak przekazów piśmiennych, umożliwiających autorowi piśmienne modelowanie opowieści o przeszłości (wyjątkiem pozostaje, jak się przyjmuje, zaginiona pasja św. Wojciecha) ${ }^{11}$. Tendencja ta jest „wygodna”, przykładowo, Krzywousty to „dubler”12 Bolesław Chrobrego,

\footnotetext{
7 O uwarunkowaniach tego typu polemik (prolepsis) zob. G. Simon, Untersuchungen zur Topik der Widmungsbriefe mittelalterlicher Geschichtsschreiber bis zum Ende des 12. Jahrhunderts, „Archiv für Diplomatik, Schriftgeschichte, Siegel- und Wappenkunde" 1958 [cz. 1] oraz 1959/1960 [cz. 2]. Do rzeczywiście wyjątkowych przypadków należy w tej perspektywie postawa Williama z Malmesbury z jego prologu do czwartej księgi Gesta regum Anglorum (Willelmi Malmesbiriensis, Gesta regum Anglorum atque Historia novella, vol. 2, recensuit Th. Hardy, Londini 1840 , s. 483): „Sunt alii qui, nos ex segnitie sua metientes, impares tanto muneri existimant, et hoc studium prava suggillatione contaminant. Quapropter jam pridem, vel illorum ratiocinio vel istorum fastidio perculsus, in otium concesseram, silentio libenter adquiescens [...]" (,Są inni, którzy oceniając nas z perspektywy swojej gnuśności, uważają, że my nie sprostamy tak wielkiemu obowiązkowi i to zamiłowanie wyszydzają złym zniesławieniem. Dlatego już wcześniej uderzony wnioskowaniem tych lub lekceważeniem tamtych oddałem się bezczynności, odpoczywając chętnie w milczeniu") (G. Simon, Untersuchungen zur Topik, tu cz. 1, s. 91 i przypis 29).
}

8 "Barbarus", jak za L. van Ackerem przypomina Kazimierz Liman (Kilka uwag o topice w "Kronice polskiej” Galla Anonima, „Symbolae Philologorum Posnaniensium Graecae et Latinae” 1973, s. 157), oznacza także „pogański”. Piśmienność stawać się więc może dla Galla wyrazem chrześcijańskości.

9 Zob. szerzej W. Wojtowicz, Tarda loquendi facultas - tożsamość tzw. Galla Anonima w kontekście listów i epilo-

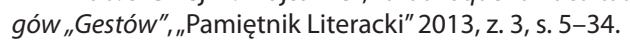

$10 \mathrm{Na}$ "wyraźną pracę kompozycyjną, kontrasty i paralele" zwracała uwagę już Brygida Kürbis, zalecając ostrożność w „przyjmowaniu Gallowych przebarwień” (B. Kürbis, op. cit., s. 179).

11 O ile nie mamy do czynienia z fingowaniem znajomości tekstu, postrzeganego z pewnością przez Galla jako źródło prawdy i autorytetu. Uznanie Liber de passsione martiris jako możliwej fikcji Galla - najbliżej takiego ujęcia pod wpływem Jerzego Strzelczyka (idem, Bolesław Chrobry, Poznań 1999, s. 57-58), jest Przemysław Wiszewski (w Domus Bolezlai, s. 166-168, 608-615, tamże starsza literatura). Wiszewski nie wyklucza jednoznacznie istnienia takiego źródła (z którego Gall nie korzysta przy omawianiu działalności św. Wojciecha): Gall wspomina o nim, aby wzmocnić znaczenie swoich słów. Podobnie sądzi Gerd Althoff, zwracając uwagę, że pewne szczegóły narracji Gallowej nie miały prawa pojawić się w pasji - nie zawdzięcza ich Gall temu hipotetycznemu tekstowi (Spielregeln und Ironie im Gallus Anonymus, „Frühmittelalterliche Studien“ 2007, s. 408 i n.). Dyskusję wokół zaginionej pasji (przyjmując jej istnienie) - zob. D. Bagi, Królowie węgierscy w „Kronice” Galla Anonima, Kraków 2008, s. 75 i n.; czy wcześniej M. Plezia, Kronika Galla na tle historiografii XII wieku, Kraków 1947, s. 188-190; oraz M. Plezia, Najstarszy zabytek historiografii polskiej, [w:] idem, Od Arystotelesa do Złotej Legendy, Warszawa 1958, s. 291-305.

12 To narracyjne dublowanie postaci traktuję jako niezwykle silny sygnał oralności przetwarzanych przez Galla opowieści. Już w Gallowej narracji o Popielu para gości ma odpowiednik w parze synów Popiela (zob. E. Skibiński, Elementy historii oralnej w kronikach Galla Anonima i Wincentego Kadłubka, s. 68). 
przywracający status pristinus wielkiego przodka, tworzący „drugi początek” ${ }^{3}$. Bolesław Chrobry to ideał władcy dla Bolesława III, daje on kontury tej „nowej” postaci. Polityka zewnętrzna ogniskuje się wokól podporządkowania sobie pogańskich sąsiadów i ustanawiania dla nich biskupstw - takie jest przesłanie narracji Galla w odniesieniu do Bolesława i jego praprawnuka ${ }^{14}$.

Ta praktyka Galla, tłumacząca się względami kulturowymi i poetologicznymi, wyzwala potencjał konstruowania rzeczywistości historycznoliterackiej (częstokroć wielokrotnie sprzecznej) na kanwie Gestów. (Przesłanki takiego „konstruktywistycznego” podejścia nie zawsze są oczywiste dla autorów poszczególnych ujęć) ${ }^{15}$. Nasze poznanie (przede wszystkim w humanistyce) nie odwzorowuje jednak wprost pewnego rodzaju rzeczywistości pozajęzykowej czy pozakulturowej (niezależnej od poczynań badacza i użytych narzędzi poznawczych) - jest dialogiem wewnątrz- i międzykulturowym ${ }^{16}$. Przypomnijmy: $w$ takim ujęciu historyk literatury nie rekonstruuje przeszłości, ale ją w pewien sposób konstruuje ${ }^{17}$. Debata dotycząca Galla wielokrotnie i sumiennie zapominała o tym ważnym poglądzie. Ponad pół wieku temu pisał Marian Plezia:

[... ] poglądów dotyczących kroniki, na które panowałaby w nauce powszechna zgoda, jest znikomo mało. Prawie każde mniemanie ma swoich przeciwników i nie ma teorii, która nie byłaby przedmiotem zastrzeżeń i sprzeciwów $[\ldots]^{18}$.

Ponadto, niereferencyjna topika literacka, którą Gall się posługuje, nie staje się wyrazem „kryzysu” w sposobie myślenia badaczy, ani tym bardziej nie prowadzi ku jego zakwestionowaniu poprzez założenie, że dane ujęcie nie ma odniesienia - zdawałoby się, tak oczywistego - do sfery przedmiotowej i historycznej. Interpretacje wykorzystywały topikę Galla jako podstawę dowodzenia w rozważaniach na temat rzeczywistości pozatekstowej. Stąd pochodzi niekwestionowalna pewność tego typu interpretacji, które opierają się na wybranych aspektach użytej przez Galla topiki.

Poszczególne rozwiązania narracyjne u Galla operują technikami charakterystycznymi dla świadomości ustnej - tak w zakresie zapamiętywania, jak i prezentacji treści. Przykładowo, Krzysztof Benyskiewicz twierdzil, że w kronice „Prezentacja Bolesława [Szczodrego] przypomina nieco zubożony i skrzywiony wizerunek Mieszka II”19. Bolesław

${ }_{13}$ Cz. Deptuła, Galla Anonima mit genezy Polski. Studium z historiozofii i hermeneutyki symboli dziejopisarstwa średniowiecznego, Lublin 2000, s. 330 i n.; wcześniej R. Michałowski, „Restauratio Poloniae” w ideologii dynastycznej Galla Anonima „„,Przegląd Historyczny” 1985, z. 3, s. 472-474.

14 S. Rosik, Bolesław Krzywousty, Wrocław 2013, s. 251.

15 Zob. np. dyskusję między innymi wokół przywołanego artykułu G. Althoffa (J. Banaszkiewicz, Gall jako historyk poważny, czyli dlaczego dzieje i Bolesława Chrobrego, i Bolesława Krzywoustego sa prawdziwe i niegroteskowe, „Przegląd Historyczny" 2008, z. 3, s. 399-410). Spraw tych nie można tu omawiać szerzej.

16 A. Zybertowicz, Konstruktywizm jako orientacja metodologiczna w badaniach społecznych, [w:] Światooglady historiograficzne, red. J. Pomorski, Lublin 2002, s.141. Zob. też A. Dąbrówka, Konstruktywizm w badaniach literatury dawnej, „Nauka” 2009, nr 3, s. 133-154.

17 Przykładowo: S. J. Schmidt, O pisaniu historii literatury. Kilka uwag ze stanowiska konstruktywistycznego, przeł. M. B. Fedewicz, „Pamiętnik Literacki” 1988, z. 3, s. 238 i n.; czy twórczość Haydena White'a (Tekst historiograficzny jako artefakt, przeł. M. Wilczyński, [w:] H. White, Poetyka pisarstwa historycznego, red. E. Domańska, M. Wilczyński, Kraków 2000, s. 78-109).

18 M. Plezia, Kronika Galla na tle historiografii XII wieku, s. 20. Sprawę autorstwa omawiał ostatnio J. Wenta w pracy Kronika tzw. Galla Anonima. Historyczne (monastyczne i genealogiczne) oraz geograficzne konteksty powstania (Toruń 2011, s. 12-21).

19 K. Benyskiewicz, Książę Polski Władysław Herman 1079-1102, Zielona Góra 2010, s. 89. 
w kronice Anonima ma przypominać Mieszka II, którego bliższej charakterystyki brakuje. Skrótowa relacja Anonima dotycząca panowania Mieszka II tworzy podstawę takiego zestawienia obu władców. Przemysław Wiszewski dochodzi z kolei do wniosku dotyczącego paraleli Chrobry-Szczodry. Przy swego rodzaju tożsamości politycznej poczynań obu władców, wskazuje on na „znaczącą rozbieżność” „w sferze ideowej”20. Według Wiszewskiego Bolesław Szczodry jest dla Krzywoustego przestrogą, także przykładem. Gall demonstruje, jakich cech Bolesława II nie powinien naśladować, co w konsekwencji doprowadziło imiennika do tego, że nie dorównał on wielkością Bolesławowi Chrobremu. Jedna postać dostarcza wariantywnego wzorca dla innej. Świętopołk (Swantopolc) (III 16) to negatywny w stosunku do Bolesława III (choć analogiczny - czego Gall nie chce dostrzec nazbyt zależny od kontekstowego, a nie uniwersalnego rozumienia pojęć) przykład „mężobójcy”, podany przez Boga piórem Galla „ad exemplum ad aliorum” (GC 143) ${ }^{21}$.

Narracja Galla posługuje się strukturami analogicznymi, złożonymi z podobnych, jedynie zmodyfikowanych segmentów. Każdy epizod jest epizodem starym, przekształconym, do którego dodano nowe elementy - jest to charakterystyczny „ustny” schemat budowania akcji ${ }^{22}$. (W ujęciu Paula Zumthora wskazuje się nawet, że powtórzeniom ulegają elementy ze wszystkich poziomów języka ${ }^{23}$. Powtórzenia te mogły pojawiać się w literaturze pisanej jako „ustna pozostałość” - konwencje stylu literackiego ${ }^{24}$, podjętego rozmyślnie przez Galla.

$\mathrm{Na}$ odwróconą analogię między pychą Bolesława Szczodrego a pokutą Krzywoustego wskazywała Elżbieta Kowalczyk. W swym artykule przyjmuje ona dwojaki sens tej analogii: „pokuta węgierska była taktycznym posunięciem Bolesława, pamiętnego losu stryja”, względnie - była ona „konsekwencją klątwy (?) rzuconej przez duchowieństwo życzliwe Zbigniewowi”25. Za pomocą schematu narracyjnego buduje Gall ważne przesłanie moralne i polityczne. Odmienne postawy obu Bolesławów sugerują zgoła odmienny los Krzywoustego ${ }^{26}$. Edward Skibiński dostrzega narracyjną paralelę pomiędzy przyjazdem Ottona III a, ostatecznie, konsekwencjami militarnego przedsięwzięcia Henryka $\mathrm{V}^{27}$. Dodatkowo w opisie Anonima utożsamiają się dwie wyprawy na Ruś z czasów Bolesława Szczodrego (z roku 1069 oraz z 1076, względnie 1077) ${ }^{28}$ celem osadzenia w Kijowie Izasława. Scena upokorzenia Izasława (I 23) z kolei odpowiada z kolei realiom tej drugiej ekspedycji z roku 1077, względnie $1078^{29}$. Obie wyprawy Bolesława zostały przez Galla

\footnotetext{
20 P. Wiszewski, op. cit., s. 244 i n. Autor wskazuje na „odwrócony” stosunek Szczodrego względem właściwego stosunku, charakterystycznego dla Chrobrego, np. w odniesieniu do wojów (ibidem, s. 248) czy kleru, tu w związku z „konfliktem z biskupem Stanisławem” (ibidem, s. 253).

21 Katalog przywar Świętopełka jest paralelny w stosunku do tychże cech cesarza Henryka V (zob. P. Wiszewski, op. cit., s. 328).

22 A. Lord, Właściwości literatury ustnej, przeł. P. Czapliński, „Pamiętnik Literacki” 1990, z. 1, s. 284 i n.

23 P. Zumthor, Właściwości tekstu oralnego, przeł. M. Abramowicz, „Literatura Ludowa” 1986, z. 1, s. 56-58.

24 A. Lord, op. cit., s. 285.

25 E. Kowalczyk, Krzywousty - skaza fizyczna czy moralna?, "Kwartalnik Historyczny” 1994, z. 1, s. 10-11. Zob. też Z. Dalewski, Rytuał i polityka. Opowieść Galla Anonima o konflikcie Bolesława Krzywoustego ze Zbigniewem, Warszawa 2005, s. 125, ostatnio S. Rosik, op. cit., s. 148-149.

26 S. Rosik, op. cit. s. 149.

27 E. Skibiński, Przemiany władzy. Narracyjna koncepcja Anonima tzw. Galla i jej podstawy, Poznań 2009, s. 213-214 oraz s. 236.

28 J. Powierski, Kryzys rządów Bolesława Śmiałego, Gdańsk 1992, s. 138.

29 M. Plezia, Dookoła sprawy św. Stanisława. Studium źródłoznawcze, Bydgoszcz 1999, s. 173.
} 
(lub jego informatorów) utożsamione ze sobą - Szczodry zajmuje Kijów „sicut primus Boleslaus magnus" (GC 48) ${ }^{30}$.

Podobnie możemy powiedzieć o narracji ukazującej stosunek Bolesława do króla węgierskiego, witającego Władysława z pozycji konnej (I 28) ${ }^{31}$ - zbliża się ona do potraktowania przez króla polskiego Izasława na Rusi (I 23). Jest to w istocie narracyjny (i epicki) dubler tamtego epizodu, który ma posłużyć Gallowi jako element charakterystyki postępowania Bolesława w stosunku do ustanowionych przez siebie władców, z charakterystycznym dla niego brakiem szacunku, pogardą, pychą i uporem ${ }^{32}$. Zwracał na to uwagę Edward Skibiński: „Nie ulega wątpliwości, że obie sceny są analogiczne. Sama opowieść o Bolesławie w tej wersji jest wyraźnie zbudowana na jakichś schematach należących do kultury oralnej”33. Samo zaś upokorzenie Izasława „przypomina poczynania Chrobrego”, hańbiącego siostrę władcy Rusinów ${ }^{34}$. Epizod następujący po epizodzie upokorzenia Izasława, złamania danego słowa, również dotyczy wiarołomstwa - „przewrotnej chytrości” księcia czeskiego, tym razem jednak w stosunku do Bolesława Szczodrego (I 24$)^{35}$.

Paraleli tych (szczególnie „pozytywnych”) nie ujmujemy w świetle oczywistego skądinąd, rzymskiego w rodowodzie naśladownictwa cnót (myśl powtarzana wielokrotnie przez Galla $^{36}$, choć zwracano uwagę, że „Gall obciąża winą następców Chrobrego, iż nie dorównali potędze wielkiego króla”37). Wskazuje ona na szablonowość wywodzącą się z dziedzictwa tradycji ustnych, którymi dysponowała Gall, i których siłą rzeczy nie mógł, a także nie chciał neutralizować.

Ta cecha narracji sięga podstaw samych Gestów Galla - Gesta legitymizowały władzę księcia Bolesława i jego porządek społeczny ${ }^{38}$. Dzieje się tak poprzez konstruowanie binarnej opozycji, „działającej” na wielu płaszczyznach pomiędzy Bolesławem a przyrodnim bratem - Zbigniewem ${ }^{39}$. I tak, przykładowo, Zbigniew działa za „podszeptem ludzi głupich”, Bolesław, mimo zbłądzenia, kierowany jest światłą radą „ludzi rozumnych” (III 25) ${ }^{40}$.

30 Przykładowo, można wskazać, że rozdziały II 4 i ll 5 kontaminują konfrontację polsko-węgierską z roku 1086, wojnę czesko-polską z roku 1093, bunt Zbigniewa z tegoż roku (z udziałem wrocławian), walki wewnętrzne z lat 1096-1097 (zob. K. Benyskiewicz, Książę Polski Władysław Hermann, s. 230 i n, w szczególności s. 250, tu przypis 387).

31 W podobny sposób postąpił książę Pomorzan, uznając się poddanym Bolesława (II 39) - pycha księcia zapowiada dalsze walki, P. Wiszewski, op. cit., s. 244; S. Rosik, op. cit., s. 170-171.

32 Zob. np. rozdział Pycha ukarana. Relacje między Bolesławem II Szczodrym a Władysławem I Świętym w ujęciu kroniki Anonima tzw. Galla (K. Benyskiewicz, W kręgu Bolesława Szczodrego i Władysława Hermana. Piastowie w małżeństwie, polityce i intrydze, Wrocław 2010, s. 84-87), wcześniej J. Banaszkiewicz, Czarna i biała legenda Bolesława Śmiałego, ,Kwartalnik Historyczny” 1981, nr 2, s. 353-387.

33 E. Skibiński, Przemiany władzy, s. 113, 203.

34 P. Wiszewski, op. cit., s. 244.

35 Ibidem, s. 246-247.

36 Przykładowo w (I 10) o Chrobrym „aby wspomnienie jego żywota przyniosło korzyść słuchaczom, jako wzór podany im do naśladowania” (s. 30) („eius vite recordatio ab auditoribus imitata proficiat”, s. 29) czy w (I 16) „Dlatego to tego znakomitego męża powinni w cnotach naśladować jego następcy, ażeby mogli się wznieść do takiej samy sławy i potęgi" (s. 36-37) "Quocirca talem ac tantum virum successores debent virtutibus imitari, ut valeant acquirere tantam gloriam et potentiam sublimari" (s. 36). Taki sens ma także określanie działań Szczodrego w kategoriach "okazywania się synem Kazimierza” ("ut se filium Kazimiri ostenderet”) (I 24) - por. E. Skibiński, Przemiany władzy, s. 118 i n. Zob. P. von Moos, Geschichte als Topik, Hildesheim 1996, s. 69 i n.

37 Tak E. Skibiński, Przemiany władzy, s. 84.

38 Zob. np. P. Wiszewski, op. cit., s.147-149 (tamże dalsze odwołania do literatury przedmiotu).

39 W sprawie "dekonstrukcji” metody Galla, kształtowania postaci Zbigniewa - zob. przywołane studia E. Kowalczyk-Heymej, Z. Dalewskiego.

40 Por. też II 35, II 41. Zob. też P. Wiszewski, op. cit., s. 307, 309, 311. 
Mechanizm selekcji negatywnych dla Bolesława faktów prowadzi do ich kumulacji w osobie ojca Władysława i brata Zbigniewa ${ }^{41}$ - swego rodzaju narracyjnego dublera Władysława, negatywnego spadkobiercę swego ojca.

Przykładowo, nieudana wyprawa Hermana przeciw Pomorzanom (II 3) uzyskuje narracyjnego dublera w równie nieudanym ataku Zbigniewa na kontr-Santok Pomorzan („gród przeciwny” „na wprost Santoku”, II 17), który ostatecznie sami Pomorzanie burzą. W przeciwieństwie do tych dwóch porażek, Gall głosi podwójne zwycięstwa Bolesława nad Pomorzanami: jeszcze przed pasowaniem na rycerza, i po raz wtóry, bezpośrednio przed samą uroczystością pasowania (II 17 oraz II 18) 42 $^{4}$ Dodatkowo kontrast ten jest wzmacniany jest poprzez usunięcie (przemilczenie, załagodzenie) przez Galla informacji dotyczących antagonizmów i konfliktów, także krwawych, w łonie samej dynastii Piastów ${ }^{43}$. Sam konflikt i jego konsekwencje dla Zbigniewa nie są już pokazane - Gall będzie pisał o „szkodzie nie do naprawienia" (III 25). Narracyjnym dublerem katastrofy Zbigniewa ${ }^{44}$ jest okazana nadspodziewanie opieka księcia Władysława nad bratankiem Mieszkiem Bolesławowicem przebywając pod opieką swojego stryja, niespodziewanie ginie ${ }^{45}$. Zagrożenie życia młodego Bolesława III ma swoją paralelę w niespójnym obrazie Mieszka Bolesławowica jako bezbronnego dziecka, które padło ofiarą swoich wrogów ${ }^{46}$.

Tego typu epickie paralelizowanie akcji jest rdzeniem wielu epizodów, począwszy od uczt postrzyżynowych Piasta, jego gościnności, oraz Popiela - i niegościnności jego poddanych (I 1-2 $)^{47}$, ale także tych z najbliższej Gallowi przeszłości. Przykładowo w rozdziale II 27, dotyczącym misji Walo, biskupa Beauvais, powrót tegoż do Rzymu uzyskuje narracyjną paralelę w zwróceniu się Bolesława przeciw swym wrogom ${ }^{48}$ :

Sed itaque Romane legato reverenter honorato, concilioque canonice celebrato, missus apostolica data benedictione, Romam rediit, belliger vero Bolezlauus hostes suos inpugnaturus adiit $(\text { GC } 94)^{49}$.

Skoro zatem uczczono w należyty sposób legata Stolicy Rzymskiej i kanonicznie odprawiono synod, wysłaniec udzieliwszy apostolskiego błogosławieństwa, powrócił do Rzymu, waleczny zaś Bolesław znów zwrócił się do walki ze swymi wrogami. (II 27).

Ryszard Grzesik wykazywal, że wiadomość o zdobyciu ziem naddunajskich była domysłem kronikarza, wynikającym z jego wiedzy geopolitycznej, jak również z informacji pochodzących od otoczenia. Gall świadomie przeniósł granicę na Dunaju, granicę mo-

41 K. Benyskiewicz, Książę Polski Władysław Herman, s. 409-410.

42 Zob. P. Wiszewski, op. cit., s. 290-292.

43 K. Benyskiewicz, Książę Polski Władysław Herman, s. 211 (także przypis 242 ze strony 212-213, tu s. 213) wcześniej np. C. Deptuła, Galla Anonima mit, s. 294.

44 Zob. zwłaszcza studium Dalewskiego.

45 K. Benyskiewicz, Książę Polski Władysław Herman, s. 410 (zob. też s. 201 i n.).

46 Zob. ostatnio S. Rosik, op. cit., s. 43.

47 Zob. C. Deptuła, Galla Anonima mit genezy Polski, s. 319 i n. Chrobry to "nowy Siemowit", Mieszko to odpowiednik Piasta, po Rzepce „pierwszej matce” następuję Dąbrówka (tamże, s. 321-322).

48 Wydawcy polskiego tłumaczenia (przypis 2 ze strony 118) zwracają uwagę na paralele pomiędzy oblężeniem Wielenia przez Bolesława III a oblężeniem Głogowa (III 8). Podobne uwagi mogą dotyczyć oblężenia Nakła (III 26).

49 Przykładowo, rozdział II 34 jest zbudowany wyłącznie na paralelizowanej akcji (uderzenie na Pomorzan, „wyprzedzające” kontruderzenie na Czechów). 
rawską (odpowiadało to jego intencjom), a zatem czyny Bolesława Śmiałego utożsamił z dokonaniami i czasami Bolesława Chrobrego. Obaj ci władcy musieli zostać rozróżnieni, pozytywne czyny Śmiałego zakłócałyby bieg takich utożsamień ${ }^{50}$. Oralne tendencje do jaskrawego przeciwstawiania postaci spotykają się z żywym ideologicznym zamysłem pracy Galla ${ }^{51}$. Przenoszenie czynów Bolesława Śmiałego na Bolesława Chrobrego pozwala na postawienie hipotezy, że Gall z rozmysłem intensyfikował te utożsamienia, których jako pierwsi mogli dokonać jego informatorzy.

W ten sposób Gall buduje mit Polski Bolesława, który, jak wskazuje na przykład Wiszewski, stał się ważnym elementem polskiej świadomości historycznej”². W tym kontekście zrozumiałe jest, że Szczodry nie mógł w żaden sposób powtórzyć uderzenia mieczem przez Chrobrego w Złotą Bramę, ponieważ Złota Brama w Kijowie została wzniesiona dopiero w roku 1037. Gall tworzy lub kodyfikuje tradycję gestu uderzenia w bramę mieczem jako czynu Chrobrego ${ }^{53} \mathrm{w}$ perspektywie „nieudanego” naśladownictwa cnót i czynów Bolesława I przez Szczodrego.

Tego typu „oralne” praktyki mają zastosowanie do całych schematów „historiograficznych”. Przykładowo za przyczynę nieszczęść, jakie dotknęły Polskę po śmierci Mieszka II, uznał Gall klątwę Radzima-Gaudentego: „Klęska ta zaś dlatego tak powszechnie miała dotknąć całą ziemię [polską], że podobno Gaudenty, brat i następca św. Wojciecha, z nie znanej mi przyczyny obłożył ją klątwą” (I 19). Piotr Guzowski przypuszcza, że „relacja Anonima nie odnosi się jednak do realiów pierwszej połowy XI w., ale do pierwszej połowy XII wieku i ma charakter przestrogi" ${ }^{44}$. Klątwa ta złamała (w perspektywie przyjętej przez Galla) królestwo i (w konsekwencji) kościól, jest to to zatem ostrzeżenie, by nie używać jej wobec bratobójcy, Bolesława III ${ }^{55}$. Gall ocenia sytuację Bolesława po usunięciu konkurenta do władzy z perspektywy człowieka XII wieku, świadomego znaczenia ekskomuniki nakładanej przez papieża ${ }^{56}$ - „aktualizuje” standardy kulturowe i religijne sprzed stulecia, wykorzystując oralny mechanizm homeostazy.

„Paralelizowanie” sięgać może wręcz schematów narracyjnych ujmujących specyfikę „ustroju” Pomorza oraz Śląska ${ }^{57}$, równie dobrze rysować relację między Zbigniewem i Bolesławem w kategoriach alegorycznej wykładni losów potomków Abrahama - Izmaela i Izaaka (II 3).

${ }_{50}$ R. Grzesik, Wątki południowosłowiańskie w małopolskiej tradycji historycznej XIII w., [w:] Onus Athlanteum. Studia nad kroniką biskupa Wincentego, red. A. Dąbrówka, W. Wojtowicz, Warszawa 2009, s. 291-292.

51 W. Polak zwraca uwagę, że jedną z cech tradycji ustnej jest ukazanie anegdotycznych i wyrazistych opisów (Kronika Galla Anonima a pochodzenie rodu Awdańców, [w:] Peregrinatio ad Veritatem. Studia ofiarowane profesor Aleksandrze Witkowskiej OSU z okazji 40-lecia pracy naukowej, red. A. Witkowska, U. Borkowska, C. Deptuła, R. Knapiński, Lublin 2004, s. 402), podobnie C. Deptuła, "Gesta” Gallowe, s. 71.

52 P. Wiszewski, Domus Boles/ai, s. 202 i n.

53 M. Plezia, Legenda o szczerbcu Chrobrego, [w:] Wyobraźnia średniowieczna, red. T. Michałowska, Warszawa 1996, s. 195, $200 \mathrm{i} \mathrm{n.}$

54 P. Guzowski, Konflikt biskupa Stanisława z królem Bolesławem Śmiałym. Stanowisko Kościoła wobec zamachów stanu we wczesnośredniowiecznej Polsce, [w:] Zamach stanu w dawnych społecznościach, red. A. Sołtysiak, J. Olko, Warszawa 2004, s. 266. O ile Gall nie przemilcza celowo przyczyn tego stanu rzeczy, o tyle widzimy granice pamięci informatorów Galla (ibidem, s. 267, w przypisie 27 literatura podejmująca analizę słów Galla).

55 P. Guzowski, op. cit., s. 270.

56 Ibidem, s. 267.

57 Zob. B. Kowalska, Bunt Magnusa - Anonim tzw. Gall o mechanizmach wypowiadania posłuszeństwa monarsze, [w:] Zamach stanu w dawnych społecznościach, np. s. 297). 
Charakterystyczne dla residuum oralnego jest także istnienie „ciężkich” postaci i wydarzeń $^{58}$, nacechowanych silnymi emocjami. Przejrzenie na oczy Mieszka (I 4) prowadzi do „gaudium inextrectabile”, poprzedza je to, że „laetitia alia cumulavit”, wreszcie „cunctis laetitia plena fuit” (GC 14) s9 $^{59}$ jako odwrócenie „dolor et verecundia”. Mowa Bolesława przed sławną bitwą z Rusinami (I 7) to wskazanie na drastyczną opozycję pomiędzy wieczną sławą, tryumfem, zwycięstwem panów a klęską i statusem sługi (dziedziczonym przez potomków) (I 7) ${ }^{60}$. Bezmierna rzeź sprawiona przez Bolesława przekracza możliwości opisu (co oczywiście jest spożytkowaniem „topoi niewyrażalności” $\left.{ }^{61}\right)$ :

„Nec est nostre facultatis recitare ${ }^{62}$ quantas strages sibi resistentium ibi fecit, neque quisquam valet hostium peremptorum milia certo numero computare, quos constabat ad prelium sine numero convenisse, paucosque superstites fuga lapsos evasisse" (GC 25).

I brak mi po prostu słów, jak straszną rzeź sprawił wśród tych, którzy stawili mu opór, i nikt by nie potrafił dokładną cyfrą określić tysięcy zabitych nieprzyjaciół, którzy, jak wiadomo, niezliczeni stanęli do walki, a mało który ocalił życie ucieczką. (I 7).

Sama postać Bolesława to wzorcowa i wzorowa postać „ciężka”:

Tanta virtute, tanta potentia, tantaque victoria regem Bolezlauum Deus omnipotens decoravit, quantum eius bonitatem et iustitiam erga se ipsum et homines recognovit; tanta gloria Bolezlauum, tanta rerum copia, tantaque letitia sequebatur, quantum eius probitas et liberalitas merebatur" (I9) (GC 27).

Bóg wszechmogący udzielił królowi Bolesławowi tyle dzielności, potęgi i zwycięstw, ile w nim samym obaczył dobroci i sprawiedliwości wobec siebie oraz wobec ludzi. Taka sława, taka obfitość dóbr wszelkich i taka radość towarzyszyła Bolesławowi, na jaką zasługiwała jego zacność i hojność. (I 9).

Przykłady można mnożyć niemalże dowolnie na podstawie kart każdego rozdziału (zwłaszcza z księgi I). (Podobnie: Gall nie mógł osadzić w akcji postaci „niedziałającej”, dlatego też postać bezimiennej żony Bolesława Szczodrego pojawia się dopiero w związku

58 Zob. np. W. J. Ong, Oralność i piśmienność. Słowo poddane technologii, przeł. wstęp J. Japola, Lublin 1992, s. 102 in.

59 Por. opis żałoby po śmierci Chrobrego (I 16): „Polonia auro radiante, gemmis coronata” teraz "sedet in puIvere”. Dźwięk cytry zamienia się w "luctum”, "gaudium” zaś w „meror” itd. (ibidem, s. 37-38). Zob. też Ryszard Gansiniec, Liryka Galla Anonima „ "Pamiętnik Literacki” 1958, z. 4, s. 374 i n.

60 Nie zaskakuje zatem, że w dublerze (I 10) wojny z Rusinami (I 7) to właśnie servi („cocis, inquilinis, apparitoribus, parasitis exercitus") pokonują Rusinów. Nie rozstrzygniemy, czy to asocjacyjne budowanie kolejnego chwalebnego epizodu zawdzięczamy pamięci Galla, czy tradycjom mu udostępnionymi. Zwraca uwagę jednak paralelizm tego "nowego" epizodu z życia Bolesława Chrobrego: obaj władcy (król Polski i król Rusinów) paralelnie najeżdżają swoje ziemie, obaj też paralelnie rozbijają obozy (I 10).

61 E. R. Curtius, Literatura europejska i łacińskie średniowiecze, przeł. i oprac. A. Borowski, Kraków 1997, s. 167-170 .

${ }^{62}$ Gallowe „recitare” jest synonimem pracy pisarskiej, a nie reprodukcji ustnej tekstu przy charakterystycznym dla średniowiecza współistnieniu czytania ze słuchaniem, praktyce głośnego recytowania, które zdaniem niektórych badaczy ciążyło ku swego rodzaju widowisku (np. E. B. Vitz, Orality and Performance in Early French Romance, Cambridge 1999). Taką świadomością Gall dysponował, zob. Epilog II (W. Wojtowicz, Tarda loquendi facultas, s. 22-23). Porównaj np. w rozdziale II 23: „Nos autem de peccato tractare vel iustitia materiam non habemus, sed res gestas regum ducumque Polonie sermone tenui recitamus" (GC 91). 
z pogrzebem jej syna Mieszka ([I 29] $\left.)^{63}\right)$. Jeśli Polska upada po wypędzeniu Kazimierza, to tak, że „ad tantam Polonia desolationem est redacta, quod ex toto pene diviciis et hominibus est exuta” (I 19) („W końcu zaś zarówno od obcych, jak i od własnych mieszkańców Polska doznała takiego spustoszenia, że w zupełności niemal obraną została z bogactw i ludzi”).

Gall musiał stworzyć bardzo literackie i fikcjonalne Gesta, ażeby niejako odciąć się od ustnej i ustnie przekazywanej epiki wernakularnej. Listy poprzedzające poszczególne księgi stały się środkiem obrony przed tym wernakularnym przekazem, uznaniem jego rangi ${ }^{64}$. Czytająca publiczność, przynajmniej w wypadku pierwszych dwóch listów, podejmuje się zadania integracji $\mathrm{z}$ mechanizmem kreowania fikcji. Mechanizm ten ulega osłabieniu, a może nawet załamaniu, w związku ze zniknięciem „informatorów” i pojawieniem się nieznanych bliżej kapelanów z ich pierwszoplanową funkcją. Teraz - w Liście III i w Epilogu II - uzasadnieniem istnienia opusculum staje się performatywny akt transmisji wernakularnego opus ${ }^{65}$. (Żadnego miejscae w Gestach nie można ujmować jako uwagi skierowanej do kopistów, np. aby w kopiowaniu podczas dyktowania nie doszło do zniekształcenia czy zafałszowania przekazu. Nie mamy tu wzmianek o pisemnej reprodukcji tekstu i okolicznościach tej reprodukcji, istotnych dla autora). Nowa forma recepcji w XII wieku, cicha lektura, nie wymusza na Gallu żadnej nowej techniki opowiadania. Z tej perspektywy pytanie, czy występ zakładał improwizację na podstawie Gestów, ich odczytanie, czy recytowanie opanowanego pamięciowo tekstu wcześniej zapisanego (powstaje oczywiście kwestia o języka zapisu), musi zostać uchylone. Gesta były tworzone dla czytającej, kościelnej publiczności, a nie dla tej słuchającej i świeckiej. Z tego powodu w Kronice praktycznie brak świadectw dawnej oralności wernakularnej materii, są jedynie konwencjonalne jej cechy, które jednak należą do wyznaczników epiki - konwencji podjętej przez Galla. Słuchająca publiczność powinna się, podobnie jak wcześniej, interesować niezliteraryzowanymi tekstami w oralnym obcowaniu z nimi.

Istniała zapewne faza transmisji ustnej materii Galla (zwraca uwagę problem braku poświadczeń źródłowych istnienia jokulatorów na dworach Piastów ${ }^{66}$ - tradycja ustna epickich opowieści prawdopodobnie nie była transmitowana $\mathrm{z}$ pokolenia na pokolenie przy pomocy właściwych epice technik i formularnego stylu $)^{67}$, dzieło Galla przekracza ten typ transmisji, osadzając materię w kręgu kultury pisma - z oralności pozostanie tylko jej fingo-

${ }^{63}$ Zob. też P. Wiszewski, op. cit., s. 260. Autor dostrzega też w żałobie bezimiennej matki powtórzenia „metafory Polski jako matki Bolesława I". Zob. też Cz. Deptuła, Galla Anonima mit genezy Polski, op. cit., s. 156.

${ }^{64}$ Zob. szerzej W. Wojtowicz, Tarda loquendi facultas - tożsamość tzw. Galla Anonima w kontekście listów i epilogów „Gestów”, „Pamiętnik Literacki” 2013, z. 3.

65 Zob. ibidem.

${ }^{66}$ Poświadczony źródłowo jokulator (o imieniu Jurzyk, będący szlacheckiego pochodzenia) jest znany dopiero z dworu Władysława Odonica - od czasów Galla dzieli nas prawie wiek - J. Wiesiołowski, Repertuar Jurzyka, jokulatora księcia Władysława Odonica, [w:] Wielkopolska - Polska - Europa. Studia dedykowane pamięci Alicji Karłowskiej-Kamzowej, red. J. Wiesiołowski, J. Kowalski, Poznań 2006, s. 59-61, 66-67, ostatnio o tymże Jurzyku pisała T. Michałowska: Szkice mediewistyczne, Warszawa 2014, s. 185. Charakterystyczny jest brak jakichkolwiek prób zapisu repertuaru tegoż Jurzyka, w którym istnieć musiały jakieś adaptacje epiki Zachodu - jak przyjmuje Wiesiołowski (za sprawą dworu lotaryńskiego, gdyż Ludmiła, córka Mieszka Starego, została wydana za Fryderyka Lotaryńskiego, ibidem, s. 66). Jedyne poświadczenia otrzymujemy w onomastyce (zob. też wcześniejsze prace Wiesiołowskiego: J. Wiesiołowski, Romans rycerski w kulturze społeczeństwa późnośredniowiecznej Polski, [w:] Literatura i kultura późnego średniowiecza w Polsce, red. T. Michałowska, Warszawa 1993, s. 141-151). Nie dysponujemy z tego okresu żadnym rękopisami wernakularnymi, wskazującymi na zainteresowanie literaturą świecką.

67 Dyskusja na temat formuł zob. J. Goody, Poskromienie myśli nieoswojonej, przeł. M. Szuster, Warszawa 2011, s. $136 \mathrm{in}$. 
wanie na użytek konwencji tekstu epickiego. Problem ten zwrotnie oddziałał na historyków tłumaczących rzeczywistość Gallową: ich nieuświadamiany „konstruktywizm” spotyka się z obcymi im mentalnie zabiegami Galla, tworzącego quasi-oralny tekst, siłą rzeczy pozbawiony konsekwencji w postrzeganiu świata, właściwej współczesnym badaczom.

\section{Bibliografia}

Anonim tzw. Gall, Kronika polska, przeł. R. Grodecki, przekład oprac., wstęp, przypisy M. Plezia, Wrocław: Zakład Narodowy im. Ossolińskich - Wydawnictwo, 1989.

Althoff Gerd, Spielregeln und Ironie im Gallus Anonymus, „Frühmittelalterliche Studien” 2007.

Bagi Daniel, Królowie węierscy w „Kronice” Galla Anonima, Kraków: PAU, 2008.

Banaszkiewicz Jacek, Czarna i biała legenda Bolestawa Śmiatego, „Kwartalnik Historyczny” 1981, nr 2.

Banaszkiewicz Jacek, Gall jako historyk poważny, czyli dlaczego dzieje i Bolestawa Chrobrego, i Bolestawa Krzywoustego sa prawdziwe i niegroteskowe, „Przegląd Historyczny” 2008, z. 3.

Benyskiewicz Krzysztof, $W$ kręgu Bolestawa Szczodrego i Wtadystawa Hermana. Piastowie w matżeństwie, polityce i intrydze, Wrocław: Wydawnictwo Uniwersytetu Wrocławskiego, 2010.

Benyskiewicz Krzysztof, Książę Polski Wtadysław Herman 1079-1102, Zielona Góra: Oficyna Wydawnicza Uniwersytetu Zielogórskiego, 2010.

Curtius Ernst Robert, Literatura europejska i tacińskie średniowiecze, przel. i oprac. A. Borowski, Kraków: TAiWPN Universitas, 1997.

Deptuła Czesław, Galla Anonima mit genezy Polski. Studium z historiozofii i hermeneutyki symboli dziejopisarstwa średniowiecznego, Lublin: Instytut Europy Środkowo-Wschodniej, 2000.

Dalewski Zbigniew, Rytuat i polityka. Opowieść Galla Anonima o konflikcie Bolestawa Krzywoustego ze Zbigniewem, Warszawa: Instytut Historii PAN, 2005.

Dąbrówka Andrzej, Konstruktywizm w badaniach literatury dawnej, „Nauka” 2009, nr 3.

Galli Anonymi, Cronicae et gesta ducum sive principum Polonorum, wyd., wstęp, komentarz K. Maleczyński, Kraków: PAU, 1952.

Gansiniec Ryszard, Liryka Galla Anonima, „Pamiętnik Literacki” 1958, z. 4.

Goody Jack, Poskromienie myśli nieoswojonej, przeł. M. Szuster, Warszawa: Państwowy Instytut Wydawniczy, 2011.

Green Dennis Howard, Medieval Listening and Reading. The Primary Reception of German Literature 800-1300, Cambridge-New York: Cambridge University Press, 1994.

Guzowski Piotr, Konflikt biskupa Stanistawa z królem Bolestawem Śmiatym. Stanowisko Kościoła wobec zamachów stanu we wczesnośredniowiecznej Polsce, [w:] Zamach stanu $w$ dawnych spotecznościach, red. A. Sołtysiak, J. Olko, Warszawa: Ośrodek Badań nad Tradycją Antyczną. Uniwersytet Warszawski, 2004.

Kellog Robert, Literatura ustna, przel. P. Czapliński. „Pamiętnik Literacki” 1990, z. 1.

Kowalczyk Elżbieta, Krzywousty - skaza fizyczna czy moralna?, „Kwartalnik Historyczny” 1994, z. 1.

Kowalska Barbara, Bunt Magnusa - Anonim tzw. Gall o mechanizmach wypowiadania postuszeństwa monarsze, [w:] Zamach stanu $w$ dawnych spotecznościach, red. A. Soltysiak, J. Olko, Warszawa: Ośrodek Badań nad Tradycją Antyczną. Uniwersytet Warszawski, 2004.

Kürbis Brygida, Pisarze i czytelnicy w Polsce XII i XIII wieku, [w: ] Polska dzielnicowa i zjednoczona. Państwo, społeczeństwo, kultura, red. A. Gieysztor, Warszawa: Wiedza Powszechna, 1972.

Labuda Gerard, Miejsce powstania kroniki Anonima Galla, [w:] Prace z dziejów Polski feudalnej ofiarowane Romanowi Grodeckiemu w 70 rocznice urodzin, red. K. Stachowska, Warszawa: Państwowe Wydawnictwo Naukowe, 1960. 
Liman Kazimierz, Kilka uwag o topice w „Kronice polskiej” Galla Anonima, „Symbolae Philologorum Posnaniensium Graecae et Latinae", 1973.

Lord Albert, Wtaściwości literatury ustnej, przeł. P. Czapliński, „Pamiętnik Literacki” 1990, z. 1.

Michałowski Roman, „Restauratio Poloniae” w ideologii dynastycznej Galla Anonima, „Przegląd Historyczny" 1985, z. 3.

Michałowska Teresa, Między stowem mówionym a pisanym. (O poezji polskiej późnego średniowiecza), [w:] Literatura i kultura późnego średniowiecza w Polsce, red. eadem, Warszawa: Instytut Badań Literackich Polskiej Akademii Nauk, 1993.

Michałowska Teresa, Szkice mediewistyczne, Warszawa: Instytut Badań Literackich Polskiej Akademii Nauk, 2014.

Moos Peter von, Geschichte als Topik, Hildesheim: Georg Olms Verlag 1996.

Mittelalterliche Literatur und Kunst im Spannungsfeld von Hof und Kloster Ergebnisse der Berliner Tagung, 9.-11. Oktober 1997, red. N. F. Palmer, H.-J. Schiewer, Tübingen: Max Niemeyer Verlag, 1999.

Ong Walter J., Oralność i piśmienność. Stowo poddane technologii, przeł. wstęp J. Japola, Lublin: Redakcja Wydawnictw Katolickiego Uniwersytetu Lubelskiego, 1992.

Onus Athlanteum. Studia nad kroniką biskupa Wincentego, red.A. Dąbrówka, W. Wojtowicz, Warszawa: Instytut Badań Literackich Polskiej Akademii Nauk, 2009.

Plezia Marian, Dookoła sprawy św. Stanistawa. Studium źródłoznawcze, Bydgoszcz: Wydawnictwo Homini, 1999.

Plezia Marian, Kronika Galla na tle historiografii XII wieku, Kraków: Polska Akademia Umiejętności, 1947.

Plezia Marian, Legenda o szczerbcu Chrobrego, [w:] Wyobraźnia średniowieczna, red. T. Michałowska, Warszawa: Instytut Badań Literackich Polskiej Akademii Nauk, 1996.

Plezia Marian, Najstarszy zabytek historiografii polskiej, [w:] idem, Od Arystotelesa do Ztotej Legendy, Warszawa: Instytut Wydawniczy PAX, 1958.

Polak Wojciech, Gesta Gallowe a kultura oralna, [w:] Tekst. Źródła. Krytyka. Interpretacja, red. B. Trelińska, Warszawa: Wydawnictwo DiG, 2005.

Polak Wojciech, Kronika Galla Anonima a pochodzenie rodu Awdańców, [w: Peregrinatio ad Veritatem. Studia ofiarowane profesor Aleksandrze Witkowskiej OSU z okazji 40-lecia pracy naukowej, red. A. Witkowska, U. Borkowska, C. Deptuła, R. Knapiński, Lublin: TN KUL, 2004.

Powierski Jan, Kryzys rzadów Bolesława Śmiałego, Gdańsk: Wydawnictwo Marpress, 1992.

Rosik Stanisław, Bolesław Krzywousty, Wrocław: Chronicon Wydawnictwo, 2013.

Schmidt Siegfried J., O pisaniu historii literatury. Kilka uwag ze stanowiska konstruktywistycznego, przel. M. B. Fedewicz, „Pamiętnik Literacki” 1988, z. 3.

Simon Gertrud, Untersuchungen zur Topik der Widmungsbriefe mittelalterlicher Geschichtsschreiber bis zum Ende des 12. Jahrhunderts, „Archiv für Diplomatik, Schriftgeschichte, Siegel- und Wappenkunde" 1958 [cz. 1] oraz 1959/1960 [cz. 2].

Skibiński Edward, Elementy historii oralnej w kronikach Galla Anonima i Wincentego Kadtubka, [w: ] Kultura piśmienna średniowiecza i czasów nowożytnych. Problemy i konteksty badawcze, red. P. Dymmel, B. Trelińska, Lublin: Wydawnictwo UMCS, 1998.

Skibiński Edward,: Przemiany wtadzy. Narracyjna koncepcja Anonima tzw. Galla i jej podstawy, Poznań: Instytut Historii UAM, 2009.

Strzelczyk Jerzy, Bolesław Chrobry, Poznań: Wojewódzka Biblioteka Publiczna w Poznaniu, 1999.

Targosz Karolina, Gesta principum recitata. „Teatr czynów polskich władców” Galla Anonima, „Pamiętnik Teatralny” 1980, z. 2.

Vitz Evelyn Birge, Orality and Performance in Early French Romance, Cambridge: Brewer 1999

Wenta Jarosław, Kronika tzw. Galla Anonima. Historyczne (monastyczne i genealogiczne) oraz geograficzne konteksty powstania, Toruń: Wydawnictwo Naukowe UMK, 2011. 
White Hayden, Poetyka pisarstwa historycznego, red. E. Domańska, M. Wilczyński, Kraków: TAiWPN Universitas, 2000.

Willelmi Malmesbiriensis, Gesta regum Anglorum atque Historia novella, recensuit Th. Hardy, Londini 1840.

Wojtowicz Witold, Tarda loquendi facultas - tożsamość tzw. Galla Anonima w kontekście listów i epilogów „Gestów”, „Pamiętnik Literacki” 2013, z. 3.

Wiesiołowski Jacek, Romans rycerski w kulturze społeczeństwa późnośredniowiecznej Polski, [w:] Literatura i kultura późnego średniowiecza w Polsce, red. T. Michałowska, Warszawa: Instytut Badań Literackich Polskiej Akademii Nauk, 1993.

Wiesiołowski Jacek, Repertuar Jurzyka, jokulatora księcia Wtadysława Odonica, [w:] Wielkopolska Polska - Europa. Studia dedykowane pamięci Alicji Karłowskiej-Kamzowej, red. J. Wiesiołowski, J. Kowalski, Poznań: Wydawnictwo Poznańskiego Towarzystwa Przyjaciół Nauk, 2006.

Wiszewski Przemysław, Domus Bolezlai. W poszukiwaniu tradycji dynastycznej Piastów (do okoto 1138 roku), Wrocław: Wydawnictwo Uniwersytetu Wrocławskiego, 2008.

Zumthor Paul, Wtaściwości tekstu oralnego, przeł. M. Abramowicz, „Literatura Ludowa” 1986, z. 1.

Zybertowicz Andrzej, Konstruktywizm jako orientacja metodologiczna w badaniach spotecznych, [w:] Światooglądy historiograficzne, red. J. Pomorski, Lublin: Wydawnictwo Uniwersytetu Marii Curie-Skłodowskiej, 2002. 